UDC 327.7(4:477)“19911/2019"

DOI: 10.24919/2519-058x.14.197187

\begin{abstract}
Andrii HRUBINKO
PhD hab. (History), Associate Professor, Professor of the Department of Theory and History of State and Law, Ternopil National Economic University, 46 a Mykulynetska Street, Ternopil, Ukraine, postal code 46400 (gav_tnpu@yahoo.com)
\end{abstract}

ORCID: https://orcid.org/0000-0002-4856-5831

Research ID: H-2147-2017 (https://publons.com/researcher/2114997/andriy-gav-hrubinko/)

\begin{abstract}
Андрій ГРУБІНКО
доктор історичних наук, дочент, професор кафедри теорії та історії держави і права Тернопільського національного економічного університету, вул. Микулинецька, 46a, Тернопіль, Україна, індекс 46400 (gav_tnри@уаһоо.сот)
\end{abstract}

Бібліографічний опис статті: Hrubinko, А. (2020). Ukraine in the foreign policy of the United Kingdom in the context of European integration (1991 - 2019). Skhidnoievropeiskyi Istorychnyi Visnyk [East European Historical Bulletin], 14, 153-164. doi: 10.24919/2519058x.14.197187

\title{
UKRAINE IN THE FOREIGN POLICY OF THE UNITED KINGDOM IN THE CONTEXT OF EUROPEAN INTEGRATION (1991 - 2019)
}

\begin{abstract}
The purpose of the article is to show the peculiarities of the formation, changes and implementation of the UK foreign policy towards Ukraine and its strategy of European integration in the context of the development of the EU'S CFSP at the turn of the 20th-21st centuries. The research methodology - principles of historicism, systematicity, general scientific methods of logic, comparative analysis, special-historical methods (historiographic analysis, historical-systemic, chronology, historicalgenetic). The research novelty is that it presents a history study of the formation of the UK's policy towards Ukraine since its independence in 1991 in the context of the kingdom's membership of the European Union, the formation of its foreign and security policy in the Eastern European direction. The realities of modern international relations, notably the Brexit process, the challenges and threats posed by Russian military aggression against Ukraine are taken into account. The Conclusions. The research has been established that the policy of the European Union and Great Britain towards Ukraine at the end of the XX century was formed under the influence of conjuncture of international relations. Governments of the kingdom supported the European integration of Ukraine, but in their relations with official Kyiv they took the interests of Moscow. In the early 2000s, the British government partially sacrificed its interests in Eastern Europe in favor of Russia and made compromise with the main partners in EU to expand the integration, which in the conditions of the largest in the history "wave" of the expansion didn't want to burden themselves with additional obligations. In general, Great Britain despite the volatility of the dynamics of intergovernmental relations and the complexity of the international conjuncture, acted as one of the most consistent supporters of the European integration of Ukraine. In the conditions of the beginning of the Russia's military aggression against Ukraine um 2014, the leadership of Great Britain actively supported decision of the European Union to introduce anti-Russian sanctions. Great Britain provided assistance to the Ukrainian Army and the victims of the military conflict in the East of Ukraine. However, with the exit from the EU, the strategic importance of relations with Great Britain for Ukraine as an ally will diminish significantly. The completion of the Brexit process can have negative consequences for Ukraine's international position in Europe and will strengthen the pro-Russian forces in EU.

Key words: United Kingdom, Ukraine, European integration, EU, Common Foreign and Security Policy, Brexit.
\end{abstract}




\title{
УКРАЇНА У ЗОВНІШНІЙ ПОЛІТИЦІ ВЕЛИКОЇ БРИТАНІЇ В КОНТЕКСТІ СВРОПЕЙСЬКОӤ ІНТЕГРАЦЇ̈ (1991 - 2019)
}

\begin{abstract}
Анотація. Мета дослідження - показати особливості формування та реалізації зовнішньої політики Великої Британії щодо України та їі стратегії європейської інтеграиії в контексті розвитку Спільної зовнішньої і безпекової політики (СЗБП) Європейського Союзу на рубежі XX - XXI ст. Окремо проаналізовано позицію Великої Британії щодо російської військової агресії проти Украӥни в контексті східноєвропейської політики СС. Методологію дослідження сформували принципи історизму, системності, загальнонаукові методи логіки, компаративного аналізу, спеиіально-історичні методи (історіографічного аналізу, історико-системний, хронології, історико-генетичний). Наукова новизна полягає у тому, щзо представлено дослідження історії формування політики Великої Британії щодо України після здобуття ії незалежності (1991) в контексті членства королівства у Свропейському Союзі, формування його зовнішньої і безпекової політики на східноєвропейському напрямі. Враховано реалії сучасних міжнародних відносин, насамперед прочес Brexit, виклики і загрози, пов'язані з російською військовою агресією проти України. Висновки. Політика Свропейського Союзу і Великої Британії щодо України наприкіниі ХХ ст. формувалася під впливом кон'юнктури міжснародних відносин. Уряди країни підтримували євроінтеграцію Украӥни, але зважали на інтереси Росії. На початку 2000-х рр. британський уряд частково пожертвував своїми інтересами у Східній Європі на догоду Росії і пімов на компроміс з партнерами по СС щодо розширення інтеграиіі. Загалом Велика Британія виступала одним із послідовних прихильників європейської інтеграиї України. В умовах початку військової агресії Росії проти Украӥни у 2014 р. керівництво Великої Британії активно підтримало рішення Європейського Союзу запровадити антиросійські санкиій, надавало допомогу українській армії і постраждалим у ході військового конфлікту на Сході Украйни. Однак після виходу з СС стратегічне значення відносин з Великою Британією для України зменшиться. Breхіт матиме негативні наслідки для перспектив європейської інтеграції України та посилить проросійські сили в СС.

Ключові слова: Велика Британія, Україна, європейська інтеграція, СС, Спільна зовнішня i безпекова політика, Brexit.
\end{abstract}

The Problem Statement. One of the defining events in Europe's contemporary history is Brexit, which has become a reflection and consequence of the overall crisis of European integration processes, and the Russian-Ukrainian conflict. Challenges to the modern European and world security system, one of which is Russia's international aggression, cannot be ignored by the world community, especially the European Union, the United Kingdom and Ukraine. It is against them today that these challenges are directly addressed. The development of a Common Foreign and Security Policy (CFSP), in which the United Kingdom is still playing an important role, has been a historic attempt to respond to the latest security concerns and to enhance the EU's international influence. Therefore, in the context of the transformations of the European Union's foreign and security policy in the Eastern European direction, the complex and unpredictable military and political situation in the East of Europe, it is necessary to examine the historical experience of Great Britain's policy formation towards Ukraine in the period from 1991 (gaining Ukraine's independence) until the end of 2019 (final decision by the UK leadership to leave the EU).

The Analysis of Recent Research and Publications. Ukrainian scientists V. Krushynskyi (Krushynskyi, 2004) and N. Yakovenko (Yakovenko, 2011) have given some attention to the study of the history of Britain's participation in European integration and its impact on Ukraine's international position. Among Western researchers in the history of the establishment and development of the EU's CFSP and its participation in the United Kingdom, the most important are F. Cameron (Cameron, 2007), S. Biscop (Biscop, 2012), R. Balfour (Balfour, 2013), T. Cole (Cole, 2015), I. Bond et al. (Bond, etc., 2016). Among the works 
of Russian Britons, the publications of N. Kapitonova (Kapitonova, 2003) and Al. Hromyko (Hromyko, 2014) attract attention. In general, Ukraine's place in European policy of Great Britain has not been sufficiently explored. First of all, it is necessary to study the foreign policy towards Ukraine by the Conservative governments, including in the context of the history of the Brexit process, in the period of $2010-2019$. After all, this issue of the period in all types of historiography is practically not covered.

The purpose of the article is to show the peculiarities of the formation, changes and implementation of the UK foreign policy towards Ukraine and its strategy of European integration in the context of the development of the EU's CFSP at the turn of the 20th 21 st centuries.

The Statement of the Basic Material. The policy of the European Communities on the territory of the former Soviet Union began to take shape in the last years of the USSR existence and coincided with that of its leading Member States within the framework of the European Political Cooperation Mechanism (the predecessor to the EU's CFSP). After the collapse of the USSR in Eastern European foreign policy of the United Kingdom and the European Communities / European Union, relations with Ukraine occupied a special place, which after the declaration of independence in 1991, due primarily to its territory, large population and natural resources, significant geopolitical features, a large stockpile of weapons has received close attention from the West. However, Western leaders and institutions' attitudes toward Ukraine in the early 1990s were largely biased. The United Kingdom was no exception.

Prime Minister Margaret Thatcher, visiting Ukraine in June 1990, stated in a speech to the USSR Verkhovna Rada on the call of the deputies to develop relations between countries that embassies are provided only for countries with state independence (Margaret Thatcher, 1990). Supporting the integrity of the USSR, the British leadership did not consider the possibility of separate cooperation with Ukraine. The proclamation of its statehood was interpreted as a threat to international security. At the same time, the United Kingdom became the first EU Member State to recognize Ukraine's independence on 31 December 1991. It is symbolic that on the same day Ukraine's independence was recognized by the European Communities.

One of the strategic objectives of the foreign policy of the newly created European Union in the new geopolitical environment was the formation of a zone of stability and security in the East of Europe and the expanses of the former USSR (Cameron, 2007, p. 135). First of all, it was in the countries of the near eastern periphery - Russia, Ukraine, Belarus and Moldova. The West was interested in establishing controlled and predictable processes for the development of democracy, the formation of market relations in these countries, their integration into modern international political and economic systems. Unlike the Central European countries with which the Association Agreements were concluded in the early 1990s, the EU and its Member States (including the United Kingdom) were in no hurry to allocate significant funds to help post-Soviet countries. The united Europe was interested in their restoration to the extent that they were friendly to the democratic West and did not pose a threat to European security. Therefore, in the first half of the 1990s, the British leadership's reticent attitude towards Ukraine as a likely partner was observed. In Great Britain, they favored relations with Russia as the successor to the USSR. Nuclear disarmament issues, overcoming the aftermath of the Chornobyl disaster, Russian-Ukrainian territorial disputes, the unwillingness of the British political elite to perceive Ukraine and its relations beyond Russian interests, and the 
lack of public awareness determined the nature of UK policy towards Ukraine. However, its political elite understood the role of Ukraine, its democratic development for European security, by supporting the country's involvement in regional cooperation (Department of the State Archives of the Ministry of Foreign Affairs of Ukraine - DAS MFAU, f. Osnovnyi, c. 1739, pp. 107-111).

With the active involvement of the United Kingdom, a strategy formation for EU relations with Ukraine took place. During the country's presidency of the EU Council in September 1992, the first EU-Ukraine summit was held at the highest level, which resulted in the signing of a Joint Communiqué on the start of negotiations on the preparation of the Partnership and Cooperation Agreement. During a meeting of the Ukrainian delegation with EU representatives in London in October - November 1992, a statement on the recognition of Ukraine as a part of the Central European region was published. An analysis of archival materials of interstate diplomatic contacts shows that the British side was ready to develop cooperation with Ukraine subject to its abandonment of nuclear weapons (DAS MFAU, f. Osnovnyi, c. 031 , pp. 127-128). London agreed to provide security guarantees to Ukraine, although they were of formal importance. This was openly acknowledged by the management of the Forin Office (DAS MFAU, f. Osnovnyi, c. 9559, pp. 10-11).

All post-Soviet states were granted the status of EU partners without differentiation and membership prospects, even associate ones, which had already been granted to many Central European states by that time. Development of trade, investment and technical cooperation is envisaged. However, it was not about the development of systematic interaction on foreign policy and security, involvement in EU foreign action, which revealed an underestimation of the role and importance of relations with these countries.

The completion of the nuclear disarmament process of Ukraine and the political problems of Russia's development have resulted in a gradual increase in the attention of the UK and EU leadership to relations with Ukraine (Wolczuk, 2003, p. 105). London upheld the state integrity of Ukraine in the Russian-Ukrainian dispute over the status of Crimea in the first half of the 1990s. On 29 June 1995, the British Parliament was one of the first among EU legislatures to ratify the Partnership and Cooperation Agreement between Ukraine and the EU.

Since the pro-European Labor government came to power in May 1997, London's position on Ukraine's European prospects has not changed dramatically. In response to a proposal by the Ministry of Foreign Affairs of Ukraine on the possibility of granting Ukraine the status of an associate member of the EU, which joined the EU Council during the UK's presidency in the first half of 1998, Head of the Forin Office Robin Cook in June 1998 replied that the EU vision is in the need to "make the Partnership and Cooperation Agreement with Ukraine as effective as possible". According to the Minister, the associate status of Ukraine as an associate member at this stage would be a "far-sighted step" (DAS MFAU, f. Osnovnyi, c. 030, pp. 1-2). At the Forin Office, a position was formed to grant Ukraine the status of an EU Special Partner, such as relations with NATO. It was implemented in the EU Common Strategy for Ukraine approved by the European Council on 11 December 1999. The British Government took an active position in developing a document recognizing Ukraine as a "strategic partner" of the union. The UK supported the idea of creating a free trade area between the EU and Ukraine.

Active support for the moderate development of the Community's political relations with Ukraine can be seen in the context of the overall revitalization of the EU's official EU CFSP policy, its desire to shape the agenda for political cooperation between the Allies and their relations with the nearest periphery in accordance with their traditions and interests to 
expand the EU's external influence as opposed to deepening integration (Kapitonova, 1999, p. 56). With the support of the UK Government at the EU Summit in Nice (December 2000), Ukraine was included in the list of countries whose accession was considered desirable in perspective. Kyiv was invited to begin agreeing on terms of participation in military missions under the Common Security and Defense Policy (EUSR) (EU - Ukraine Summit, 2000). According to a decision of the EU Council on Foreign Affairs, Ukraine, as a unification partner country from 2003 to 2012, participated in its police mission in Bosnia and Herzegovina.

Further transformations of UK policy towards Ukraine have confirmed its close relationship with the dynamics of EU-Ukraine relations. The deterioration of the image of Ukraine's leadership in the international arena due to scandals surrounding the "Gongadze case", the sale of weapons to Iraq, the oppression of political opposition against the background of the traditional internal problems of the country's development have determined the context of our country's relations with the EU and Great Britain in 2001 - 2004. One of the consequences of the tension in Ukraine's relations with the West was the change in the unification policy, which took place with the direct involvement of the United Kingdom. The British-Swedish Neighborhood Policy Initiative in 2002, which did not envisage the prospect of Ukraine's membership of the EU and even of the association, testified to the crisis state of its relations with the union. Not only had a prospect of Ukraine's accession to the EU the indefinite delay, but also the granting it market economy status and WTO accession. According to V.Yu. Krushynskyi, a certain change in the position of the UK leadership on the European integration of Ukraine can be seen as an interest in further developing its relations with the EU in the special status of a neighbor and part of the political game of the British leadership aimed at maintaining influence on the development of the EU and internal in the UK itself (Krushynskyi, 2004, p. 396). Also worth considering is the factor of British-Russian relations that was on the rise in the early 2000s. London partially sacrificed its interests in Eastern Europe to please Moscow's interests, compromised with EU partners (notably Paris and Berlin), who, in the history of the largest ever "wave" of enlargement, did not wish to burden themselves with post-Soviet obligations.

Despite the period of tension in EU-Ukraine relations, it was obvious to all parties that cooperation was needed. According to V. Kopiika, the European Neighborhood Policy has become a kind of compromise between the interests of the EU and Ukraine (Kopiika, 2005, p. 9). In general, the British leadership was able to distinguish between the critical attitude towards the leadership of Ukraine and the interests of interstate cooperation. The country's government continued to support Ukraine's European and Euro-Atlantic integration. The deterioration of relations between Great Britain and Russia has played a major role in this. The United Kingdom - Poland - Ukraine cooperation was a testament to the British side's interest in deepening EU-Ukraine relations.

In practice, the European Neighborhood Policy, especially in its eastern dimension, has proved to be an ineffective foreign policy mechanism. In the EU's military-restricted field, it has not been able to significantly influence the resolution of any of the long-running conflicts in its periphery, such as in Transnistria. Limited assistance has been made available to many neighboring countries. The main focus was on the development of cross-border cooperation programs and the development of security at the eastern borders. The 2003 British Initiative to create an area of temporary detention of illegal migrants in Ukraine as a mechanism to curb the flow of migrants to Europe testified to the exceptionally pragmatic task of supporting Ukraine's European aspirations in the United Kingdom. 
The prospects for the development of relations between Ukraine and the countries of the West were in fact dependent on the level of conduct and results of the 2004 presidential election. The political situation in Ukraine was perceived in the West at the same time as a test of the ability to transfer power on the basis of democratic principles regardless of Russia and as an important step to guarantee security and stability in the region. Influenced by the events of the end of 2004, significant changes in its perception of the British public were observed in Ukraine. According to European Commission polls, in 2005, 45\% of Britons supported Ukraine's accession to the EU (35\% - against), which was one of the highest in Western Europe and coincided with the EU average. According to these data, the United Kingdom was ahead of Germany, Italy, France, the Netherlands and several other countries in Western Europe (Estontsi.., 2005). Considerable attention from the British public and the views of political circles have shown that the events of the 2004 Orange Revolution confirmed the importance of Ukraine's geopolitical role in Europe and its distinction from Russia.

Another positive factor for Ukraine was the consensus of the British political elites on the prospects of its Euro-Atlantic integration. This was evidenced by the statements of the leaders of the leading political parties. In particular, a statement by the British Parliament was released in March 2008, in which representatives of three leading political parties (Labor, Conservatives and Liberal Democrats) supported Ukraine's aspirations to become a member of the EU, calling for quick negotiations on a strengthened agreement (Pres reliz MZS Ukrainy, 2008). On 1 December 2005 (for the first time since 1996), the Prime Minister of Great Britain, who chaired the EU Council, visited the EU-Ukraine Summit in Kyiv. During this period, Ukraine was granted market economy status. Ukraine was given the opportunity to join the EU position on international issues. The real result of the Ukrainian side's involvement in the CFSP was the intensification of international negotiations on the settlement of the Transnistrian conflict, the opening of an EU border mission on the Ukrainian-Moldovan border in November 2005. Issues of development of Ukraine and Ukrainian-British relations have become frequent topics for discussion, statements by politicians, analytical notes and reviews of the British press, the vast majority of which were positive.

The critical attitude of the British politicum to the state of implementation of the European Neighborhood Policy draws attention. According to British parliamentarians, the EU has pursued an insufficiently active and indecisive policy towards Ukraine. During a parliamentary debate on Ukraine in April 2008, Minister for Europe John Murphy stated that in other European capitals there was some fatigue from EU enlargement, but not in London (Ukraine, 2008). At the same time, despite the positive attitude of British political circles to the prospects of Ukraine's integration into the EU, the official position of the Kingdom at the stage of adopting the Eastern Partnership was to support the deepening of these relations without defining membership prospects (Cole, 2015). The UK leadership once again decided to compromise with EU partners (notably France and Germany), which did not consider the practical possibility of Ukraine's membership in the union.

The intensification of relations between the Western countries (primarily the United States and the United Kingdom) with Russia in 2007 - 2008 again drew greater attention to the strategic importance of Ukraine in the Central and Eastern Europe region as a factor in curbing Russian ambitions. New opportunities have emerged to deepen Ukraine's integration into NATO, namely joining the Membership Action Plan. However, as in the case of the EU, there was no single position among Western European members. Following the results of the Alliance's Bucharest Summit, 2-4 April 2008, the position of Germany and France post- 
poned the issue of providing such a plan for Ukraine. The United Kingdom and the United States have again come to a compromise with NATO partners who have avoided resolving political issues, taking into account interests of Russia.

An additional argument for Ukraine's support for Ukraine's Euro-Atlantic integration was the Russian-Georgian armed conflict in August 2008, which drew attention to Ukraine as well. Since the beginning of the conflict, representatives of the United Kingdom have participated in international negotiations at the UN, EU, NATO, G7 and OSCE levels. A number of statements were made by the British leadership in which Russia's actions condemned and upheld Georgia's state-territorial integrity. All responsibility for hostilities in London was placed on Moscow. Even then, Western analysts warned that pro-Russian Crimea, i.e. Ukraine, could become the next target of Russian aggression (Kuzio, 2009, p. 367). As it was noted by Financial Times analyst T. Barber, in order to prevent a crisis in Ukraine, the $\mathrm{EU}$ is in dire need of developing a compelling strategy for removing the country from the geopolitical status of "no-man's land" in which it found itself after the collapse of the USSR (Barber, 2008, p. 4). It is no accident that on 27 August 2008, after the visit to Tbilisi, the head of the Forin office, D. Miliband, made an official visit to Kyiv, where he outlined a radical strategy for UK international policy. It was based on the concept of "unwavering action", which included support for allies, including Ukraine, which should become a full member of the EU and NATO.

The EU has not provided Ukraine with a real strategy for deepened cooperation. At the same time, the union itself has a split over the main issue - the right of Ukraine to membership. Despite the international situation, one of the reasons for questioning Ukraine's ability to become a full member of the EU and NATO was the internal political crisis in 2005 - 2008 . Political instability has become a good reason for the EU decision to postpone the association agreement. Given the unfavorable political situation in the EU, which has undergone a difficult process of reform, weakening the influence of Great Britain in reunification and rethinking relations with the new USA administration, Ukraine's unwillingness to deepen relations with the EU, London has not been able to fulfill Kyiv's foreign policy goal rapprochement with Brussels. We also do not exclude a significant amount of declarations in the statements of British officials in support of Ukraine's EU and NATO membership, which were made against the background of the struggle for spheres of influence in both organizations. We note the general underestimation of the importance of the Eastern Europe region in the United Kingdom, which in the second half of the 2000s lost its influence on the EU's Eastern European policy (Balfour, 2013).

The coalition of Conservatives and Liberal Democrats, which formed the next UK government in May 2010, has continued Labor's overall political stance on Ukraine. The new Minister for Europe D. Lidington, during his visit to Ukraine on 13 October 2010, stated the Government's principled willingness to support the conclusion of free trade and association agreements between Ukraine and the EU. However, anti-democratic tendencies in the domestic politics of the Presidential Administration of Ukraine Viktor Yanukovych during 2010 - 2014 had a negative impact on its perception in the United Kingdom. At the same time, criticism of the domestic policy of the Ukrainian leadership did not exclude the continued support by the British side of the process of deepening relations between Ukraine and the EU in the preparation of the Association Agreement.

In the context of the escalation of permanent diplomatic, cultural, ideological, economic and military-political confrontation in Europe, which is directly related to the deployment of 
Russian aggression against Ukraine, the European security system as well as the system of international relations in general entered a period of sharp exacerbation of the latent crisis. Opposition by powerful geopolitical players - key actors in the European security system (on the one hand, the US, NATO, the EU, and on the other - Russia), has revealed, for the first time in the post-bipolar world, unresolved and often hidden problems and gaps in Western policy. The weakness of the West (primarily EU Member States) in its relations with Russia was clearly evident during the events of its military aggression on the territory of Ukraine. The annexation of Crimea in March 2014 was condemned by the international community, but did not affect the actions of the aggressor. Europe and the US have shown an unwillingness to develop the conflict in Eastern Europe. On 1 September 2014, EU High Representative for Foreign and Security Policy F. Mogherini announced the termination of partnership with Russia. However, the use of EU military or police resources was not discussed. The Union has failed the Eastern Partnership policy due to its strategic limitation and lack of a defense component. The association could not offer anything to Ukraine in the field of defense except the traditional "soft power" methods. The EU reaffirmed its unwillingness to act as a full-fledged center of force in world politics.

In the current context, it is NATO that is Ukraine's only possible effective ally in defending aggression from the East. The clear position of the United States, Great Britain, Canada, the Baltic States, several other countries since the first days of the conflict, their diplomatic, military-technical, intelligence and humanitarian assistance have become a decisive impetus for the gradual formation of an adequate position and concrete actions of the states and institutions of Europe in the context of the escalation of Russian aggression. At the same time, none of Ukraine's partners was in a hurry to provide offensive weapons in the hope of a de-escalation of the conflict. No one is ready for a full-scale war in Europe.

The events in Ukraine have actually led to another split among EU countries, this time in terms of loyalty to Russian politics. At the institutional level, in particular the decision-making of the European Council as the supreme body of the CFSP, the EU has formally acted unanimously. For example, sanctions were imposed on Russia. In June 2015, the European Parliament adopted a resolution whereby Russia lost its status as an EU strategic partner. However, the leading Member States, primarily France and Germany, play a major role. The participation of their leaders in the "Norman format" of the negotiations on the settlement of the conflict testified to the actual transfer of the EU of its foreign policy functions to the interstate level and another recognition of the Franco-German tandem as a driver of the CFSP. The anti-Russian group included the United Kingdom, Sweden and, above all, the Baltic States and Poland, which are a potential target of Russian aggression. At the same time, a strong pro-Russian lobby does not stop operating in the EU and NATO. The influential part of the political elite of Austria, Italy, Slovakia, Hungary, etc. stands for removal of sanctions from Russia.

From the first days of aggression by Russian troops in the Crimea, the United Kingdom strongly condemned such actions and supported the initiative to exclude the Russian Federation from the G8 (The EU and Russia.., 2015, p. 7). The official London was one of the initiators of EU sanctions, one of the first to express its readiness to provide financial and military-technical assistance to Ukraine, unambiguously supported the Association Agreement with the EU. The British Government has played an important role in persuading other EU Member States, in particular, Germany, of the need to take economic pressure on Russia (Bond I., etc., 2016, p. 7). However, the isolationist policy of D. Cameron government in 
Europe's foreign policy has shown a loss of real opportunities for the UK to lead the integration process in foreign policy and security in the context of a general EU crisis. At the same time, Germany became increasingly influential within the framework of the CFSP. This was evidenced by the absence of a UK representative in the "Normandy format" negotiations on the settlement of the conflict in Ukraine. Official London is viewed in Russia itself as a Washington satellite, weakening its potential as a possible negotiator.

Allocation of about 1 million GBP for the acquisition of non-lethal military equipment (tents, heating equipment, and winter clothing kits) and armored vehicles was one of the practical measures of British assistance to Ukraine. Hundreds of British military trainers have been provided to train Ukrainian units. The British side provided medical equipment, night vision devices, GPRS navigators and computer equipment. At the end of 2015, the UK government allocated 1.5 million GBP in support of the entrepreneurship of IDPs from the Donbass and the same amount for the International Committee of the Red Cross to provide humanitarian assistance to residents of the territories of the eastern regions not controlled by Ukraine. In total, from the beginning of 2014 to the middle of July 2016, the United Kingdom helped Ukraine to the amount of \$ 5 million USD (4th place from all donor countries after USA, Canada and Poland). For comparison, since the beginning of 2014, the United States has transferred property worth over 117.5 million USD to Ukraine (Popovych \& Kudryk, 2016). The ability to assist the Ukrainian army with weapons from the UK will depend directly on the development of the situation in Ukraine and the USA position.

The referendum of 23 June 2016 and the official start of the Brexit process on 29 March 2017 marked the beginning of a new period in the history of the CFSP and the UK's relations with the EU. The practices of its senior governing bodies in 2016 - 2019 have shown that Member States are gaining experience of discussing and taking decisions without the involvement of the United Kingdom, which has gradually reduced its staff presence in the merging structures. After a prolonged political crisis on 31 January 2020, the country left the EU. The main task of the parties is to find the format of cooperation in the new conditions by concluding agreements on trade, economic and security cooperation. Brexit, because of its incompleteness and insufficient predictability of consequences, has added additional uncertainty to the future of the CFSP. The prospect of the EU getting rid of such a specific participant of integration as the UK leads to ambiguous considerations - its exit from the EU can both give impetus to the development of the CFSP and slow it down without the availability of British resources. Traditionally, there is no unity among EU Member States about the need to deepen the integration of foreign and security policy, which, among other things, is the reluctance to incur additional defense spending. As S. Biscop noted, "the problem with European defense is that it cannot function with the United Kingdom but cannot function without it" (Biscop, 2012, p. 1297). This is particularly worrying in the face of Russia's continued aggression in the east of Ukraine and NATO transformation.

The Brexit process has weakened the international position of individual Eastern European countries (primarily Ukraine), which has set itself the task of deepening relations with the union until membership. Among the negative consequences of Brexit for Ukraine is, first of all, the strengthening of loyal or openly pro-Russian sentiment in a number of EU Member States, which is one of the main challenges to its functioning. The leading EU countries France and Germany were no exception, which, after leaving the EU by the UK, became dominant in shaping its foreign and security policy. Their leadership shows a clear loyalty to the leadership of Russia. Such loyalty is manifested, in particular, in fostering the 
leadership of Russia in the strategically important issue of slowing down EU enlargement, primarily at the expense of the interests of post-Soviet states. On 5 February 2020, the European Commission, taking advantage of proposals by French President E. Macron, who had recently opposed the accession to the EU of new states, unveiled new approaches to the enlargement policy, which significantly increased the requirements for candidate countries. Even the countries of the nearest turn of Balkan Peninsula are unlikely to join the union in the short term (A more credible.., 2020). The EU-Russia rapprochement delayed the deepening of Ukraine's European integration and in the face of Russian military aggression threatened its state sovereignty. That is, the exit of Great Britain, whose official position on EU enlargement has traditionally been based on the principle of "enlargement instead of deepening", can be regarded as a loss of Ukraine's important ally in the European integration, complicating its chances for further development of relations with the EU, especially the distant prospect of membership.

After leaving the EU, the UK loses direct influence on the formation and implementation of the CFSP. Therefore, the context of British-Ukrainian relations will no longer be based on the priority of European integration issues, but will be formed on the basis of building a strategy for the development of bilateral relations and multilateral cooperation, primarily in the NATO-Ukraine format. It is NATO's mechanisms (with the coordination of positions and actions from the US) that have remained the most effective channel for the UK's influence on international security in the CEE region, in particular for Ukraine, in the face of the Russian threat. At the same time, while maintaining a certain level of UK involvement in CFSP cooperation, it will be able to influence EU eastern policy as a leading European NATO member state, a leading European technology country, to foster a favorable European position against Ukraine and to assist it with the Russian aggressor. Moreover, the efforts of France and Germany to resolve the conflict in the Donbass do not produce significant results. At the same time, one should take into account the traditional significant dependence of UK foreign policy on US international policy, regional and global environment. Therefore, its policy towards Ukraine will depend on many factors, first of all the relations between Washington and Moscow, London and Brussels, tendencies of development of Ukraine itself.

The Conclusions. The UK and EU policy towards Ukraine in the late twentieth century formed under the influence of international relations. It went from formalizing relations, biased attitudes to the new state, and establishing constructive cooperation. The UK's position on Ukraine's European integration has evolved. From the early 1990s, it felt inertia the decisive influence of the Russian factor. This impact only weakened significantly during the 2004 Orange Revolution and as a result of Russia's military aggression against Ukraine in 2014. The UK governments first largely declarative, and subsequently practically supported, deepening Ukraine's relations with the EU, favoring its long-term membership. At the same time, the West has generally been in no hurry to provide our country with significant assistance and prospects of joining European integration structures and NATO, traditionally in view of its relations with Russia.

With the EU's main focus on enlargement at the expense of Central European states, the new post-Soviet states became in the background of its Eastern European policy. This reality was evidenced by the European Neighborhood Policy, initiated by the UK Government in 2002. In general, EU Eastern policy was shaped by its Member States' relations with Russia and remained a peripheral component of the CFSP of the EU. At the same time, since the second half of the 2000s, the United Kingdom has pursued a more remote policy from Russia 
than a number of other EU countries, contributing to the gradual deepening of interest in Ukraine as an important partner.

Until the 2014 events, the UK governments did not consider Ukraine as a major strategic country for guaranteeing security in the CEE region. The United Kingdom was primarily interested in Ukraine as an element of the stability zone at the EU's eastern borders. The official London has always declared support for Kyiv's European course, but has largely acted in the context of an overall moderate unification line on this issue. In the conditions of Russian aggression, the British governments actively supported the EU decision to impose anti-Russian sanctions and provide assistance to Ukraine, provided political and material support. However, Brexit has minimized the impact of the UK on the formation and implementation of the CFSP of the EU. Britain's exit from the EU has weakened Ukraine's position in the European integration process, and its strategic importance as a partner of our country will diminish.

Acknowledgments. I express sincere gratitude to all members of the editorial board for consultations provided during the preparation of the article for printing.

Funding. The author received no financial support for the publication of this article.

\section{BIBLIOGRAPHY}

A more credible. (2020). A more credible, dynamic, predictable and political EU accession process Commission lays out its proposals. Commission lays out its proposals for EU accession process. European Commission. URL: https://ec.europa.eu/commission/presscorner/detail/en/ip_20_181. [in English]

Balfour, R. (2013). Can the EU have a foreign and security policy without Britain? A grim and insular picture of the future. URL: http://www.epc.eu/pub_details.php?cat_id=13\&pub_id=3238. [in English]

Barber, T. (2008). Ukraine strategy. Financial Times, 27 August, 5. [in English]

Biscop, S. (2012). The UK and European defense: leading or leaving. International Affairs, 88:6, 1297-1313. [in English]

Bond I., Besch, S., Gostyńska-Jakubowska, A., Korteweg, R., Mortera-Martinez, C. \& Tilford, S. (2016). Europe after Brexit. Unleashed or undone? London, 15 p. [in English]

Cameron, F. (2007). An Introduction to European Foreign Policy. London, New York, 255 p. [in English]

Cole, T. (2015). The UK must stand tall in EU neighbourhood. British influence, 2015, July 10. URL: http://www.britishinfluence.org/the_uk_must_stand_tall_in_eu_neighbourhood. [in English]

Estontsi. (2005). Estontsi i hreky duzhe khochut bachyty Ukrainu v YeS, frantsuzy y italiitsi napolovynu [Estonians and Greeks very much want to see Ukraine in the EU, the French and Italians half]. Ukrainska Pravda - Ukrainian Pravda, 21 lypnia 2005. URL: http://www.pravda.com.ua/ news/2005/07/21/3011867. [in Ukrainian]

EU-Ukraine Summit. (2000). EU-Ukraine Summit. Joint statement. Conseil/00/312. European Comission. Press Release Database. Paris, 15 September 2000. URL: europa.eu/rapid/press-release_ PRES-00-312_en.doc. [in English]

Hromyko, Al. A. (2014). Dilemmy Britanii. Poisk putei razvitiia [Dilemmas of Britain. Search of ways for development]. Moskva: Institut Yevropy RAN, 480 p. [in Russian]

Kapitonova, N. K. (2003). Velikobritaniya $v$ kontse XX-nachale XXI veka: ot konservatorov $k$ leyboristam [Great Britain at the end of the XXth - XXIth centuries: from Conservatives to Labor]. Moskva, 128 p. [in Russian]

Kopiika, V. V. (2005). Stanovlennia novoho formatu vidnosyn mizsh Ukrainoiu ta YeS [The formation of a new format of relations between Ukraine and the EU]. Visnyk Kyivskoho natsionalnoho universytetu imeni Tarasa Shevchenka. Mizhnarodni vidnosyny - Bulletin of Taras Shevchenko National University of Kyiv. International Relations, 31-32, 7-11. [in Ukrainian]

Krushynskyi, V. Yu. (2004). Velykobrytaniia v yevropeiskykh intehratsiinykh protsesakh [United Kingdom in European Integration Processes]. (Doctoral dissertation). Kyiv. [in Ukrainian] 
Kuzio, T. (2009). Strident, Ambiguous and Duplicitous Ukraine and the 2008 Russia-Georgia War. The Journal of Post-Soviet Democratization, 17(4), 350-372. [in English]

Margaret Thatcher. (1990). Margaret Thatcher. Speech to Ukrainian Supreme Soviet. Kiev. 19 Jun 1990. Margaret Thatcher Foundation. URL: http://www.margaretthatcher.org/document/108116. [in English]

Popovych, D. \& Kudryk, V. (2016). Viina na Donbasi: yaki krainy zakhodu dopomahaly Ukraini [Donbass War: Which Western Countries Helped Ukraine]. Apostrof - Apostrophe, 3 serpnia 2016. URL: http://apostrophe.ua/ua/article/ politics/2016-08-03/voyna-na-donbasse-kakie-stranyi-zapadapomogali-ukraine/ 6566. [in Ukrainian]

Pres reliz MZS Ukrainy. (2008). Pres reliz MZS Ukrainy [Ministry of Foreign Affairs of Ukraine Press Release]. 11 bereznia 2008 roku. URL: http://www.mfa.gov.ua/mfa/ua/news/detail/11392.htm. [in Ukrainian]

The EU and Russia. (2015). The EU and Russia: before and beyond the crisis in Ukraine. House of Lords European Union Committee. 6th Report of Session 2014-15. HL Paper 115. London, 123 p. [in English]

Ukraine (2008). Column 122WH - continued. 30 Apr 2008. UK Parliament Website. Publications and records. URL: http://www.publications.parliament.uk/pa/cm200708/cmhansrd/cm080430/ halltext/80430h0009.htm. [in English]

Viddil derzhavnoho arkhivu MZS Ukrainy [Department of the State Archives of the Ministry of Foreign Affairs of Ukraine - DAS MFAU].

Wolczuk, R. (2003). Ukraine's Foreign and Security Policy 1991 - 2000. London and New York, 216 p. [in English]

Yakovenko, N. L. (2011). Velyka Brytaniia v mizhnarodnykh orhanizatsiiakh [The United Kingdom in international organizations]. Kyiv: Kyivskyi universytet, 400 p. [in Ukrainian]

The article was received on April 24, 2019. Article recommended for publishing 26/02/2020 